\section{Water conservation behaviors among beginning farmers in the western United States}

\author{
K. Hilimire and K. Greenberg
}

\begin{abstract}
Beginning farmers are a critical demographic in the context of a dwindling farm population in the United States. Research has shown that beginning farmers differ from established farmers in demographic parameters, farm size, education, and access to land. It is important to understand whether these differences play out in natural resource management. In this paper, we examine how beginning farmers in the western United States defined, prioritized, and practiced water conservation during a period of water scarcity. We used a survey to assess farmer engagement with water conservation practices and binary logistic regression to test the role of various predictor variables for explaining farmer engagement with these conservation practices. The majority of respondents were organic growers with an average of 4.6 years of experience in agriculture. Respondents reported using irrigation improvements, soil health practices, and experimentation with drought-tolerant crops in response to drought conditions. Approaches for improving soil were the most frequently cited means of water conservation. Binary logistic regression revealed that a sense of stewardship and education level played significant and positive roles in predicting respondents' use of both building soil organic matter and using pressure irrigation as water conservation strategies. Understanding how beginning farmers engage in water conservation is key to supporting increased conservation engagement for this population.
\end{abstract}

Key words: agriculture— beginning farmers — binary logistic regression — stewardship identity— water conservation

The United States has experienced a dramatic shift in the farming population over the last three decades, characterized by a decline in the number of farmers (we will use the term "farmer" in this paper to refer to both crop and livestock agriculturalists) and an aging of the farming population. During this period, the average age of a farmer increased from 50.5 to 58.3, and the total number of farms decreased by 15\% (USDA 2014). Fewer farmers and the prospect of imminent retirement for established farmers have created urgency for understanding the needs of beginning farmers and crafting policies to support them (Niewolny and Lillard 2010; Ahearn 2011; Bubela 2016; Katchova and Ahearn 2016; USDA 2017). Beginning farmers are typically defined as principal operators with 10 years or less of farming experience (Williamson 2014). These farmers comprised $17 \%$ of the pared to $24 \%$ of established farmers (USDA 2017). Beginning farmers are also more likely to seek continuing education opportunities than established farmers (Bailey et al. 2014).

Land access is an ongoing challenge for beginning farmers (Niewolny and Lillard 2010; Beckett and Galt 2013). Although most farmers acquire their land by purchasing it from a nonrelative, beginning farmers are even more likely to do so, meaning that the high cost of land in many agricultural regions poses a barrier to beginning farmers (Ahearn 2011; Katchova and Ahearn 2016). Access to credit can also be a challenge for beginning farmers, especially young farmers (Kauffman 2013). Beginning farmers tend to operate smaller farms than the national average; 97\% of beginning farmers grossed less than US $\$ 350,000$ in 2012 as compared to $<50 \%$ for all farms (USDA 2017). Similar to other US farmers, approximately $60 \%$ of beginning farmers also have off-farm jobs (Bubela 2016).

The trend toward declining numbers of beginning US farmers has attracted substantial attention from policymakers and advocates (Katchova and Ahearn 2016). The policies and programs crafted to support beginning farmers must be responsive to the unique needs of this group. What has worked historically to support established farmers may not work for beginning farmers. In order to sustain beginning farmers and craft appropriate policies and programs, it is critical to know how this group practices agriculture and conceptualizes natural resource management.

Western Water Scarcity and Beginning Farmers. Much of the literature on beginning farmers has examined their characteristics, values, and economic constraints (Katchova and Ahearn 2016). However, there is a gap in the literature on how this group conceptualizes and practices natural resource management, despite the fact that many federal support programs for beginning farmers emphasize natural resource conservation (Sureshwaran and Ritchie 2011; Katchova and Ahearn 2016). In this paper, we will examine beginning farmers and

Kathleen Hilimire is an assistant professor in the Environmental Studies Program at Fort Lewis College in Durango, Colorado. Kate Greenberg is the Colorado commissioner of agriculture and the former western director for National Young Farmers Coalition in Denver, Colorado. 
water resource management with a focus on the western United States. The West, defined to include the states of Arizona, California, Colorado, Idaho, Montana, Nevada, New Mexico, Oregon, Utah, Washington, and Wyoming, produces over half of the fruits, vegetables, and nuts grown in the United States (USDA 2015). Yet this region has fewer beginning farmers than other important agricultural regions in the United States, such as the South or Midwest (Ahearn 2011; USDA 2017). Agriculture in the western United States is particularly dependent on supplemental irrigation; $70 \%$ of water use is accounted for by irrigated agriculture as compared to $32 \%$ for the United States as a whole (Maupin et al. 2014). The reliance on supplemental irrigation makes agriculture in this region particularly vulnerable to shifts in water availability, and water scarcity has strongly impacted the western region of the United States throughout the first decades of the 21st century. Changing precipitation patterns have resulted in lower than average stream flows, less late-winter snowfall, and altered stream flow regimes (Melillo et al. 2014). This has, in turn, increased pressure on groundwater resources. During the timeframe of this study in the summer of $2015,60 \%$ of the West was under moderate to severe drought conditions caused by a lack of precipitation and hotter than average temperatures that intensified evapotranspiration (NOAA 2015). These drought conditions began in 2012, creating noteworthy circumstances for investigating how beginning farmers responded to conditions of water scarcity. This information can be used to better align programs designed to encourage water conservation with the needs of beginning farmers.

Farmer Engagement with Natural Resource Conservation. The literature on farmer conservation of natural resources is extensive but reveals few universal relationships (Knowler and Bradshaw 2007; Prokopy et al. 2008; Baumgart-Getz et al. 2012; Reimer et al. 2012; McGuire et al.2013; Furman et al.2014; Floress et al. 2017). Knowler and Bradshaw (2007) conducted a global meta-analysis of farmer engagement with conservation agriculture, a suite of soil-conserving strategies largely predicated on no- or low-till practices. They assessed many of the independent variables commonly hypothesized to drive farmer engagement with natural resource conservation, such as farmer age, education, wealth, farm size, and attitudes toward conservation, but found no consistent pattern for what predicted assumption of conservation behaviors. Prokopy et al. (2008) analyzed 55 US studies published over a 25 -year period, assessing drivers for adoption of agricultural pollution-mitigating best management practices. Similar to the previous study, they found no consistent predictor variables.

Other studies have found a role for identity theory in understanding how farmers define, prioritize, and practice conservation, providing important conceptual frameworks for critically examining the drivers, expression, and dynamism of farmer identities. McGuire et al. (2013) posit the notion of a "good farmer identity," comprised of different attributes such as conservationist or productivist. These attributes are positioned in a hierarchy by individual farmers, with the result that farmers who place production high in their identity as "good farmers" prioritize production-oriented outcomes, such as yield, over conservation outcomes. Farmers with conservation higher in the identity hierarchy are more likely to take action and leadership roles for conservation. Essentially, all farmers strive to be "good farmers," and for some, that means taking conservation action while for others, that means prioritizing production. Reimer et al (2012) identified a similar trend in a study on farmer conservation behaviors and attitudes in Indiana, situating farmer attitudes into three categories of (1) farm as business, (2) off-farm environmental benefits, and (3) stewardship. Researchers found that $40 \%$ of respondents identified economic constraints as barriers to engagement with conservation behaviors, typifying the "farm as business" attitude toward conservation. This stands in contrast to the other two attitudes; farmers with a dedication to "off-farm environmental benefits" engaged with conservation strategies, not because they coincided with production benefits, but rather from a sentiment that locally healthy environments, as in regional water quality, were important. Farmers with a "stewardship" mindset were somewhat similar to farmers in the "off-farm environmental benefits" category in that they were willing to sacrifice production for conservation but for different reasons. These farmers saw themselves as caretakers of their lands (i.e., their farms) for future generations or higher powers. The authors found that most participants fell somewhere between feeling constrained by the farm as a business and valuing environmental practices. These middle adopters were most likely to practice a particular conservation strategy when it had strong on-farm benefits, and they were least likely to take on a practice whose sole purpose was an off-farm benefit for environmental quality (Reimer et al. 2012). Others have found evidence for this idea that farmers engage in environmental behaviors when they are profitable (Carolan 2006; Ahnström et al. 2009).

Taken together, it can be seen that several factors influence the intention to engage in conservation behavior, but what actually catalyzes the shift from intention to action? Focusing events can play an important role for causing this shift. A focusing event is commonly understood as an unexpected occurrence that triggers changes in policy and/or mobilizes public demand for action (Birkland 1998; Kingdon 2011). For example, severe fires occurred in South America's Paraná River Delta in 2008 caused by a combination of slash-and-burn pasture management, winds, and dry weather (Berardo et al. 2015). These fires caused policymakers and the public to seriously consider natural resources mismanagement, a problem that had long been occurring in the area but that did not trigger action until the focusing event of the fires took place. Birkland et al. (1998) identify four areas of potential change following a focusing event: (1) reshaped agendas of advocacy organizations, (2) elevation of a particular issue in policymaking, (3) formation of stakeholder groups with agendas related to the issue, and (4) advocacy groups working to build or minimize attention to the issue. In the case of farmers, focusing events can activate conservation values. Corn (Zea mays L.) farmers in Iowa were motivated by a US Environmental Protection Agency "impaired" listing of a creek in their watershed that prompted farmer concerns about regulatory enforcement if they did not respond to the listing (McGuire et al. 2013). Following the listing, conservationist farmers took a leadership role in addressing the agricultural pollution, and productivist farmers elevated their conservation activities in line with what the conservationist leader farmers were doing. The highly publicized drought in the West during the time of this study may have served as a focusing event for participants in this research. 
Research Objectives. The study presented here seeks to address a research gap on beginning farmers by investigating how beginning farmers in the western United States defined, prioritized, and practiced water conservation in this region during a period of water scarcity. Specifically, we sought to address the following questions:

1. How were beginning western farmers affected by the drought period?

2. What measures were beginning western farmers taking to conserve water, if any?

3. What variables explained why beginning western farmers engaged with particular water conservation techniques?

\section{Materials and Methods}

Survey. We used an online survey to collect data from farmers. The Institutional Review Board at Fort Lewis College approved the research on February 25, 2015 (IRB2015-0292). For the purposes of this study, we defined the western states as Arizona, California, Colorado, Idaho, Montana, Nevada, New Mexico, Oregon, Utah, Washington, and Wyoming. In order to target beginning farmers specifically, we offered the survey through the National Young Farmers Coalition (NYFC) listserv. NYFC is a national nonprofit that seeks to represent beginning farmers; its listserv reaches a network of 2,000 members. The survey instrument was aimed at assessing the perceptions, experiences, and values of beginning western agriculturalists with water through a combination of multiple choice and open-ended questions, separated into categories of "Challenges on your farm or ranch," "About your water," "Water conservation practices," "Drought and water policy," and various respondent characteristic questions. The final survey consisted of 32 questions and was offered to farmers for voluntary completion via an online collector for 30 days from May to June of 2015. The first step for data analysis was to exclude survey respondents outside of the target group. Of the 699 total respondents, 284 were actively engaged with farming or ranching, resided in the western United States, and had been in agriculture for 10 or fewer years.

Data Analysis. We used Statistical Package for Social Sciences (SPSS) Version 24 for all statistical analyses with an alpha level of $\leq 0.05$. We used logit models to analyze the role of assorted covariates in predicting engagement with water conservation practices. For logit models, we sought to understand what influenced farmers in how they had responded to drought conditions and created a series of binary logistic models to analyze the role of predictor variables on the following three categories of water conservation practices: (1) those that improve soil organic matter, (2) those that improve irrigation water use efficiency, and (3) those that emphasize low water crops. We created the models with each dependent variable coded as a binary, 0 or 1 (table 1). For each model, we used the independent variables of land tenure, USDA Natural Resources Conservation Service (NRCS) support, drought as a top concern, water availability and/or access as a top concern, stewardship named as a conservation driver, perception of "use it or lose it" water policies, years farming, farm size, gender, and highest degree obtained (table 1).

\section{Results and Discussion}

Results. Consistent with the target sample for this research, all respondents had 10 or fewer years of experience, with an average of 4.6 years in agriculture. Respondents were farmers and ranchers from California (25\%), Colorado (21\%), Washington (13\%), New Mexico (11\%), Oregon (11\%), Arizona (7\%), Utah (4\%), Montana (4\%), Wyoming (2\%), Idaho $(1 \%)$, and Nevada (<1\%) $(n=284)$. Land tenure was split among respondents into own (33\%), rent (32\%), and other (35\%). Respondents grew and raised a variety of agricultural products, with the majority (78\%) growing organic vegetables (table 2). Most respondents (89\%) produced at least one alternative agricultural product, defined as organic or grassfed. The average farm size was 343 ha $(847 \mathrm{ac})$, but this number was inflated by a small number of large farms. Most respondents (84\%) farmed 20 ha (50 ac) or less, much smaller than a typical US farm. Similarly, the number of respondents participating in some form of alternative agriculture was much higher than the general population of US farmers. As such, these results best represent small-scale, alternative western agriculture.

Most respondents thought that water conservation was important (98\%), and nearly as many reported using water conservation practices on their farm or ranch (94\%). We asked respondents how they had been affected by the recent drought, and top responses were irrigation improvements (44\%), soil health practices (37\%), and exper- imentation with drought-tolerant crops (33\%) (table 3).

When we asked about specific water conservation approaches, respondents named a variety of approaches (table 4). We coded these responses into three water conservation types that closely mirrored the top responses from table 3: (1) those that improve soil moisture holding capacity, (2) those that improve irrigation water use efficiency, and (3) those that emphasize low water crops. Overall, the number of responses was highest for techniques that improved soil moisture holding capacity $(n=1,021)$, followed by practices that improved irrigation water use efficiency $(n=600)$, and then approaches that emphasized low water crops $(n=202)$.

We then used binary logistic regression to analyze what predicted respondent likelihood of using one of the categories of water conservation. The results from the logistic regression models revealed some significant predictor variables, but none of the models completely predicted the characteristics that would make a respondent likely to choose one of the categories of conservation practices. We present each of these in turn below.

The overall logistic regression model for building soil organic matter as a water conservation approach was statistically significant $\chi^{2}(12)=35.315, p=0.000$. The Nagelkerke $R^{2}$ value was 0.305 , and the model correctly assigned $85.8 \%$ of cases. According to the model, statistically significant parameters for predicting whether a respondent would name building soil organic matter as a water conservation approach were land tenure, stewardship, and education (table 5). Specifically, respondents who owned their land were significantly less likely (odds ratio $=0.291$ ) than those who rented their land to use building soil organic matter as a water conservation strategy. Respondents who named stewardship as a driver for their water conservation were 5.385 times more likely to use building soil organic matter as a water conservation strategy than those who did not name stewardship as a driver. Survey respondents with a college degree were 3.937 times more likely to use building soil organic matter as a water conservation strategy than those with only a high school degree.

The overall logistic regression model for using pressure irrigation as a water conservation approach was statistically significant $\chi^{2}(12)=25.972, p=0.011$. The Nagelkerke $R^{2}$ value was 0.180 , and the model correctly 
Table 1

Variables used in binary logistic regression models.

\begin{tabular}{|c|c|}
\hline Variable code & Description of variable code \\
\hline \multicolumn{2}{|c|}{ Dependent variables } \\
\hline SOM & $1=$ Respondent used building soil organic matter as a water conservation tactic, $0=$ Otherwise \\
\hline CROPS & $1=$ Respondent planted drought-tolerant crops as a water conservation tactic, $0=$ Otherwise \\
\hline \multicolumn{2}{|c|}{ Independent variables } \\
\hline LAND TENURE & $1=$ Own, $0=$ Rent \\
\hline WATER & $1=$ Respondent named water availability and/or access as a top concern, $0=$ Otherwise \\
\hline STEWARDSHIP & 1 = Respondent cited stewardship as a water conservation driver, 0 = Otherwise \\
\hline USE IT OR LOSE IT & 1 = Respondent reported farming in an area where water policy encouraged users to "use it or lose it", $0=0$ therwise \\
\hline YEARS FARMING & Years, given as an integer \\
\hline FARM SIZE & Acres, given as an integer \\
\hline
\end{tabular}

\section{Table 2}

Agricultural goods produced by respondents; percentages do not total 100 because many respondents produced more than one crop or livestock type.

\begin{tabular}{lrll}
\hline Agricultural product type & $\boldsymbol{n}$ & $\begin{array}{l}\text { Percentage of } \\
\text { total } \\
\text { respondents (\%) }\end{array}$ & $\begin{array}{l}\text { Alternative } \\
\text { (organic or grassfed) }\end{array}$ \\
\hline Vegetable, organic & 222 & 78 & Alternative \\
Fruit/orchard, organic & 120 & 42 & Alternative \\
Livestock, organic or grassfed & 101 & 36 & Alternative \\
Floriculture, organic & 51 & 18 & Alternative \\
Hay/alfalfa/grass pasture & 50 & 18 & Not alternative \\
Dairy, organic & 31 & 11 & Alternative \\
Vegetable, conventional & 20 & 7 & Not alternative \\
Grain, organic & 20 & 7 & Alternative \\
Livestock, conventional & 12 & 4 & Not alternative \\
Grain, conventional & 8 & 3 & Not alternative \\
Dairy, conventional & 4 & 1 & Not alternative \\
Floriculture, conventional & 2 & 1 & Not alternative \\
& & & \\
\hline
\end{tabular}

assigned $66.1 \%$ of cases. According to the model, statistically significant parameters for predicting whether a respondent would name pressure irrigation as a water conservation approach were stewardship and education (table 6). Specifically, respondents who named stewardship as a driver for their water conservation were 2.741 times more likely to use pressure irrigation as water conservation than those who did not name stewardship as a driver. Likewise, respondents with a graduate degree were 3.941 times more likely to use pressure irrigation approaches than those with only a high school degree.
The overall logistic regression model for use of low-water crops as a water conservation approach was not statistically significant Nagelkerke $R^{2}$ value was 0.121 , and the model correctly assigned $61.7 \%$ of cases.

Discussion. The respondents in this study were beginning farmers in the western United States during a time of drought that affected much of the region. Our first research objective was to assess how beginning western farmers were impacted by the drought period. The overall picture painted by the results showed beginning western farmers engaging more deeply with water conservation than $\chi^{2}(12)=17.289, p=0.139$ (table 7). The before the drought. The top responses were all related to strategies for using less water, specifically irrigation improvements (44\%), soil health practices (37\%), and experimentation with drought-tolerant crops or livestock (33\%). Just $18 \%$ of respondents reported no effect from the drought, 11\% lost crops or livestock, and $10 \%$ took area out of production. These results suggest that the drought served as a focusing event for changing how beginning western farmers approached water conservation.

Our second research objective was to understand exactly what measures were being taken by beginning western farmers to conserve water. We found that most respondents (85\%) named building soil organic matter as a water conservation approach, and respondents named strategies that increase soil moisture holding capacity 1.7 times more frequently than irrigation-based strategies and 5.1 times more frequently than low-water crop strategies. In analyzing these data further, we found that a sense of stewardship and education played a role in predicting respondents' use of both building soil organic matter and using pressure irrigation as water conservation strategies. This is consistent with other studies that have also found that stewardship identity motivates engagement with conservation techniques (Reimer et al. 2012; McGuire et al. 2013). We also found that renters were more likely than land owners to name building soil organic matter as a water conservation tactic. This was a somewhat unexpected finding, given that improving the water holding capacity of 
Table 3

Responses to the question "How has drought affected you? PLEASE CHECK ALL THAT APPLY."

\begin{tabular}{lll}
\hline Response & $\boldsymbol{n}$ & $\begin{array}{l}\text { Percentage of total } \\
\text { respondents (\%) }\end{array}$ \\
\hline I improved irrigation timing and application & 124 & 44 \\
I implemented soil health practices & 104 & 37 \\
I experimented with drought-tolerant crops & 95 & 33 \\
I used my own money to upgrade irrigation technology & 85 & 30 \\
No effect & 51 & 18 \\
I implemented soil moisture monitoring & 38 & 13 \\
Don't know & 32 & 11 \\
I lost my crop(s) or livestock & 32 & 11 \\
I took acres out of production & 28 & 10 \\
I used a cost-share program such as NRCS to upgrade & 17 & 6 \\
$\quad$ irrigation technology & & \\
I utilized deficit irrigation & 16 & 6
\end{tabular}

\section{Table 4}

Water conservation practices used by respondents.

\begin{tabular}{|c|c|c|c|}
\hline Water conservation practice & $n$ & $\begin{array}{l}\text { Percentage } \\
\text { of total } \\
\text { respondents } \\
(\%)\end{array}$ & $\begin{array}{l}\text { Water } \\
\text { conservation } \\
\text { type }\end{array}$ \\
\hline Building soil organic matter & 242 & 85 & SOIL \\
\hline Cover cropping & 210 & 74 & SOIL \\
\hline Crop rotation & 202 & 71 & SOIL \\
\hline Pressure irrigation (i.e., sprinklers or drip) & 174 & 61 & IRRIGATION \\
\hline Mulching & 170 & 60 & SOIL \\
\hline Irrigation scheduling & 156 & 55 & IRRIGATION \\
\hline Planting drought tolerant crops & 134 & 47 & CROPS \\
\hline No-till & 101 & 36 & SOIL \\
\hline Conservation tillage & 96 & 34 & SOIL \\
\hline Water catchment & 81 & 29 & IRRIGATION \\
\hline Rotational grazing & 79 & 28 & OTHER \\
\hline Gray water recycling & 72 & 25 & IRRIGATION \\
\hline Dry farming & 68 & 24 & CROPS \\
\hline Soil moisture monitoring & 62 & 22 & IRRIGATION \\
\hline Reduce number of irrigated acres & 49 & 17 & OTHER \\
\hline $\begin{array}{l}\text { Conveyance system improvements } \\
\text { (i.e., ditch lining) }\end{array}$ & 31 & 11 & OTHER \\
\hline Flow meters & 26 & 9 & IRRIGATION \\
\hline Other & 18 & 6 & OTHER \\
\hline Deficit irrigation & 16 & 6 & IRRIGATION \\
\hline Tailwater recycling & 7 & 2 & IRRIGATION \\
\hline Smart technology (i.e., automated headgate) & 6 & 2 & IRRIGATION \\
\hline
\end{tabular}

soil through increasing organic matter can be a long-term process.

Ultimately, none of the models perfectly predicted farmer engagement with the three categories of water conservation practices; pseudo-R values ranged from 0.180 to 0.305 . This points to a need for future research with additional independent variables to construct models that better explain patterns of conservation engagement. In particular, there is a need for understanding how alternative and conventional begin- ning farmers differ in their approaches to water conservation. Given that most of our respondents were practitioners of alternative agriculture, the focus on soil organic matter as a water conservation strategy may reflect the systems philosophy common to alternative agriculture (Altieri 1995; Francis et al. 2003; Gliessman 2004). One respondent even said, "Soil health is the key to reducing water consumption...lack of soil health... [is] the primary cause of...the over consumption of water as an agricultural resource." We could not study a conventional/alternative comparison with these data because most respondents were practitioners of alternative agriculture (89\%), making the sample size of conventional too small.

Another important concept not tested in this research is the idea that social networks can play a role in the diffusion of innovative conservation practices (Reimer et al. 2014). Social clustering of conservation behaviors is partially explained by the norming of these behaviors within social groups but is also connected to concepts of risk mitigation and knowledge sharing. This is seen in the concept of "demonstration effects," which holds that engagement with environmentally beneficial farming practices is diffused through informal observation (Makita 2016). Several studies have found a preference among beginning farmers for experiential learning in group settings that emphasize social networks (Trede 2000; Bailey et al.2014). Finally, there is a need to understand the biophysical impacts related to this research (Reimer et al. 2014). Given the importance that respondents placed on building soil organic matter as a water conservation tactic, it is important to measure how much water use is actually curtailed by farmers using this approach.

\section{Summary and Conclusions}

The respondents of this survey were beginning farmers with an average of 4.6 years of experience in agriculture. Most respondents were organic growers with small farms less than 20 ha $(50 \mathrm{ac})$. In response to drought conditions, respondents reported actively conserving water, primarily with irrigation improvements, soil health practices, and experimentation with drought-tolerant crops. Approaches for improving soil were the most frequently cited means of water conservation followed by irrigation. Respondents' reasons for using soil and irrigation approaches for water conservation were not entirely 
Table 5

Logistic regression results predicting respondents' use of building soil organic matter as a water conservation approach.

\begin{tabular}{|c|c|c|c|c|c|c|}
\hline Predictor variables & $\boldsymbol{\beta}$ & S.E. of $\beta$ & Wald & d.f. & $p$-value & $e \beta$ (odds ratio) \\
\hline LAND TENURE & -1.234 & 0.539 & 5.250 & 1 & $0.022 *$ & 0.291 \\
\hline NRCS & -1.174 & 0.659 & 3.170 & 1 & 0.075 & 0.309 \\
\hline WATER & 0.746 & 0.545 & 1.876 & 1 & 0.171 & 2.108 \\
\hline STEWARDSHIP & 1.684 & 0.600 & 7.883 & 1 & $0.005^{*}$ & 5.385 \\
\hline USE IT OR LOSE IT & 0.653 & 0.564 & 1.339 & 1 & 0.247 & 1.921 \\
\hline GENDER & 0.679 & 0.509 & 1.778 & 1 & 0.182 & 1.972 \\
\hline EDUCATION & & & 4.605 & 3 & 0.203 & \\
\hline EDUCATION (technical school) & 20.142 & $15,133.310$ & 0.000 & 1 & 0.999 & $559,415,486$ \\
\hline EDUCATION (college degree) & 1.370 & 0.676 & 4.115 & 1 & $0.042 *$ & 3.937 \\
\hline EDUCATION (graduate degree) & 0.615 & 0.692 & 0.788 & 1 & 0.375 & 1.849 \\
\hline
\end{tabular}

Notes: S.E. = standard error. Wald = Wald test. d.f. = degrees of freedom. NRCS = USDA Natural Resources Conservation Service.

$*$ Significant at alpha level $\leq 0.05$.

Table 6

Logistic regression results predicting respondents' use of pressure irrigation as a water conservation approach.

\begin{tabular}{|c|c|c|c|c|c|c|}
\hline Predictor variables & $\beta$ & S.E. of $\beta$ & Wald & d.f. & $p$-value & e $\beta$ (odds ratio) \\
\hline LAND TENURE & -0.494 & 0.349 & 1.997 & 1 & 0.158 & 0.610 \\
\hline NRCS & -0.517 & 0.526 & 0.968 & 1 & 0.325 & 0.596 \\
\hline WATER & 0.521 & 0.370 & 1.986 & 1 & 0.159 & 1.684 \\
\hline STEWARDSHIP & 1.008 & 0.351 & 8.238 & 1 & $0.004 *$ & 2.741 \\
\hline USE IT OR LOSE IT & -0.321 & 0.364 & 0.778 & 1 & 0.378 & 0.725 \\
\hline FARM SIZE & 0.000 & 0.000 & 0.479 & 1 & 0.489 & 1.000 \\
\hline GENDER & -0.362 & 0.356 & 1.032 & 1 & 0.310 & 0.696 \\
\hline EDUCATION & & & 7.181 & 3 & 0.066 & \\
\hline EDUCATION (technical school) & -0.389 & 1.076 & 0.131 & 1 & 0.718 & 0.678 \\
\hline EDUCATION (college degree) & 1.016 & 0.556 & 3.333 & 1 & 0.068 & 2.761 \\
\hline EDUCATION (graduate degree) & 1.371 & 0.610 & 5.047 & 1 & $0.025 *$ & 3.941 \\
\hline
\end{tabular}

Notes: S.E. = standard error. Wald = Wald test. d.f. = degrees of freedom. NRCS = USDA Natural Resources Conservation Service.

$\star$ Significant at alpha level $\leq 0.05$.

explained by the data analysis, but a sense of stewardship, education level, and land tenure all played a role. This information can be used to develop agricultural education and support programs in ways that speak particularly to beginning farmers.

\section{Acknowledgements}

We would like to thank the farmers and ranchers who participated in this research and shared their valuable insight about agriculture and water. Thank you to Becky Clausen (associate professor of sociology and human services, Fort Lewis College,
Durango, Colorado) for collaboration on research design and data collection. Students at Fort Lewis College (Durango, Colorado) contributed to this research through pilot studies and literature review: Jacob Bigham, Kyle Drew, Max Fields, Carly Holcomb, and Brandon Stacy. Thank you to the three anonymous reviewers whose comments improved this manuscript. Finally, we would like to thank Fort Lewis College and the National Young Farmers Coalition for funding this research.

\section{References}

Ahearn, M.C. 2011. Potential Challenges for Beginning Farmers and Ranchers. Choices. Quarter 2. http://choicesmagazine.org/choices-magazine/ theme-articles/innovations-to-support-beginning-farmersand-ranchers/potential-challenges-for-beginningfarmers-and-ranchers.

Ahnström, J., J. Höckert, H.L. Bergeå, C.A. Francis, P. Skelton, and L. Hallgren. 2009. Farmers and nature conservation: What is known about attitudes, context factors and actions affecting conservation? Renewable Agriculture and Food Systems 24:38-47.

Altieri, M. 1995. Agroecology: The Science of Sustainable Agriculture. Boulder, CO: CRC Press.

Bailey, N.E., S.K. Arnold, and C.G. Igo. 2014. Educating the future of agriculture: A focus group analysis of the programming needs and preferences of Montana 
Table 7

Logistic regression results predicting respondents' use of low-water crops as a water conservation approach.

\begin{tabular}{|c|c|c|c|c|c|c|}
\hline Predictor variables & $\beta$ & S.E. of $\beta$ & Wald & d.f. & $p$-value & e $\beta$ (odds ratio) \\
\hline LAND TENURE & -0.240 & 0.333 & 0.520 & 1 & 0.471 & 0.787 \\
\hline NRCS & -0.943 & 0.545 & 2.993 & 1 & 0.084 & 0.389 \\
\hline DROUGHT & 0.581 & 0.408 & 2.027 & 1 & 0.154 & 1.788 \\
\hline WATER & 0.698 & 0.345 & 4.098 & 1 & $0.043 *$ & 2.010 \\
\hline STEWARDSHIP & 0.095 & 0.324 & 0.086 & 1 & 0.770 & 1.100 \\
\hline USE IT OR LOSE IT & 0.574 & 0.347 & 2.738 & 1 & 0.098 & 1.775 \\
\hline YEARS FARMING & 0.089 & 0.062 & 2.074 & 1 & 0.150 & 1.093 \\
\hline FARM SIZE & 0.000 & 0.000 & 0.831 & 1 & 0.362 & 1.000 \\
\hline GENDER & -0.198 & 0.334 & 0.353 & 1 & 0.553 & 0.820 \\
\hline EDUCATION & & & 2.925 & 3 & 0.403 & \\
\hline EDUCATION (technical school) & 1.458 & 1.044 & 1.949 & 1 & 0.163 & 4.297 \\
\hline EDUCATION (college degree) & 0.367 & 0.555 & 0.437 & 1 & 0.509 & 1.443 \\
\hline EDUCATION (graduate degree) & 0.722 & 0.592 & 1.489 & 1 & 0.222 & 2.058 \\
\hline Constant & -1.293 & 0.687 & 3.541 & 1 & 0.060 & 0.274 \\
\hline
\end{tabular}

Notes: S.E. = standard error. Wald $=$ Wald test. d.f. $=$ degrees of freedom. NRCS = USDA Natural Resources Conservation Service.

*Significant at alpha level $\leq 0.05$.

young and beginning farmers and ranchers. Journal of Agricultural Education 55:167-183.

Baumgart-Getz, A., L.S. Prokopy, and K. Floress. 2012. Why farmers adopt best management practice in the United States: A meta-analysis of the adoption literature. Journal of Environmental Management 96:17-25.

Beckett, J., and R.E. Galt. 2013. Land trusts and beginning farmers' access to land: Exploring the relationships in coastal California. Journal of Agriculture, Food Systems and Community Development 4:19-35.

Berardo, R., A. Lavers, and T. Olivier. 2015. Focusing events and changes in ecologies of policy games: Evidence from the Paraná River Delta. Review of Policy Research 32:443-464

Birkland, T.A. 1998. Focusing events, mobilization, and agenda setting. Journal of Public Policy 18:53-74.

Bubela, H.J. 2016. Off-farm income: Managing risk in young and beginning farmer households. Choices: The Magazine of Food, Farm and Resource Issues 31:1.

Carolan, M.S. 2006. Social change and the adoption and adaptation of knowledge claims: Whose truth do you trust in regard to sustainable agriculture? Agriculture and Human Values 23:325-339.

Floress, K., S. García de Jalón, S.P. Church, N. Babin J.D. Ulrich-Schad, and L.S. Prokopy. 2017. Toward a theory of farmer conservation attitudes: Dual interests and willingness to take action to protect water quality. Journal of Environmental Psychology 53:73-80.

Francis, C., G. Lieblein, S. Gliessman, T.A. Breland, N. Creamer, R. Harwood, L. Salomonsson, J. Helenius, D. Rickerl, R. Salvador, M. Wiedenhoeft, S. Simmons, P. Allen, M. Altieri, C. Flora, and R. Poincelot. 2003. Agroecology: The ecology of food systems. Journal of Sustainable Agriculture 22:99-118.

Furman, C., C. Roncoli, D. Nelson, and G. Hoogenboom. 2014. Growing food, growing a movement: Climate adaptation and civic agriculture in the southeastern United States. Agriculture and Human Values 31:69.
Gliessman, S. 2004. Integrating agroecological processes into cropping systems research. Journal of Crop Improvement 11:61-80.

Katchova, A.L., and M.C. Ahearn. 2016. Dynamics of farmland ownership and leasing: Implications for young and beginning farmers. Applied Economic Perspectives and Policy 38:334-350.

Kauffman, N.S. 2013. Credit markets and land ownership for young and beginning farmers. Choices 28:1-5.

Kingdon, J.W. 2011. Agendas, Alternatives, and Public Policies. London: Longman Publishing Group.

Knowler, D., and B. Bradshaw. 2007. Farmers' adoption of conservation agriculture: A review and synthesis of recent research. Food Policy 32:25-48.

Makita, R. 2016. A role of fair trade certification for environmental sustainability. Journal of Agricultural and Environmental Ethics 29:185-201.

Maupin, M.A., J.F. Kenny, S.S. Hutson, J.K. Lovelace, N.L. Barber, and K.S. Linsey. 2014. Estimated Use of Water in the United States in 2010. US Geological Survey Circular 1405. Reston,VA: US Geological Survey.

McGuire, J., L.W. Morton, and A.D. Cast. 2013 Reconstructing the good farmer identity: Shifts in farmer identities and farm management practices to improve water quality. Agriculture and Human Values 30:57-69.

Melillo, J.M., T.C. Richmond, and G.W.Yohe. 2014. Climate Change Impacts in the United States: The Third National Climate Assessment. Washington, DC: US Global Change Research Program.

Niewolny, K.L., and P.T. Lillard. 2010. Expanding the boundaries of beginning farmer training and program development: A review of contemporary initiatives to cultivate a new generation of American farmers. Journal of Agriculture, Food Systems, and Community Development 1:65-88.

NOAA (National Oceanic and Atmospheric Administration). 2015. State of the Climate: Drought for August 2015. Asheville, NC: NOAA National Centers for Environmental Information.
Prokopy, L.S., K. Floress, D. Klotthor-Weinkauf, and A. Baumgart-Getz. 2008. Determinants of agricultural best management practice adoption: Evidence from the literature. Journal of Soil and Water Conservation 63(5):300-311, doi:10.2489/jswc.63.5.300.

Reimer, A.P., A.W.Thompson, and L.S. Prokopy. 2012. The multi-dimensional nature of environmental attitudes among farmers in Indiana: Implications for conservation adoption. Agriculture and Human Values 29:29-40.

Reimer, A., A. Thompson, L.S. Prokopy, J.G. Arbuckle, K. Genskow, D. Jackson-Smith, G. Lynne, L. McCann, L.W. Morton, and P. Nowak. 2014. People, place, behavior, and context: A research agenda for expanding our understanding of what motivates farmers' conservation behaviors. Journal of Soil and Water Conservation 69(2):57A-61A, doi:10.2489/jswc.69.2.57A.

Sureshwaran, S., and S. Ritchie. 2011. U.S. Farm Bill Resources and Programs for Beginning Farmers. Choices 26.

Trede, L.D. 2000. Educational needs and perceptions of Iowa beginning farmers toward their education. Journal of Agricultural Education 41:39-48.

USDA. 2014. 2012 Census Highlights. Washinton, DC: USDA National Agricultural Statistics Service. https:// www.nass.usda.gov/Publications/Highlights/index.php.

USDA. 2015. 2012 Census of Agriculture: Specialty Crops. Washington, DC: USDA National Agricultural Statistics Service.

USDA. 2017. Beginning Farmers and Age Distribution of Farmers. Washington, DC: USDA Economic Research Service. http://www.ers.usda.gov/topics/ farm-economy/beginning-disadvantaged-farmers/ beginning-farmers-and-age-distribution-of-farmers/.

USDA. 2017. New Farmers. Washington, DC: USDA. https://newfarmers.usda.gov/.

Williamson, J. 2014. Beginning Farmers and Ranchers and the Agricultural Act of 2014. Amber Waves 6-1A, 2A, $3 \mathrm{~A}, 4 \mathrm{~A}, 5 \mathrm{~A}, 6 \mathrm{~A}$ 